\title{
Financial and monetary policy responses to oil price shocks: Evidence from oil- importing and oil-exporting countries.
}

\author{
George Filis $^{* 1}$ and Ioannis Chatziantoniou ${ }^{2}$ \\ ${ }^{1}$ Bournemouth University, Department of Accounting, Finance and Economics, \\ The Executive Business Centre, 89 Holdenhurst Road, \\ Bournemouth BH8 8EB, UK \\ ${ }^{2}$ University of Portsmouth, Department of Economics \\ Portsmouth Business School, Richmond Building, \\ Portland Street, Portsmouth, PO1 3DE, UK
}

\begin{abstract}
In this study, we investigate the financial and monetary policy responses to oil price shocks using Structural VAR methodology. We distinguish between net oil-importing and net oil-exporting countries. Since the 80s, a significant number of empirical studies have been published investigating the effect of oil prices on macroeconomic and financial variables. Most of these studies though, do not make a distinction between oil-importing and oil-exporting economies. Overall, our results indicate that the level of inflation in both net oil-exporting and net oil-importing countries is significantly affected by oil price innovations. Furthermore, we find that the response of interest rates to an oil price shock depends heavily on the monetary policy regime of each country. Finally, stock markets exhibit a negative response to increased oil prices for almost all cases. We find evidence that the magnitude of stock market responses to oil price shocks is higher for the newly established and/or less liquid stock markets.
\end{abstract}

Keywords: Structural oil price shocks, monetary policy, stock market returns, VAR JEL: C32, E44, E52, G15, Q40

\footnotetext{
* Corresponding author: email: gfilis@ bournemouth.ac.uk, tel: 0044 (0) 1202 968739, fax: 0044 (0) 1202968833
} 


\section{Introduction}

The aim of this paper is to examine the financial and monetary policy responses to oil price shocks for five European countries; namely, the UK, Norway, Germany, France and Portugal. We also consider Russia, as it constitutes a key energy supplier of Europe. In particular, both the level of inflation and interest rates will be used as proxies of the monetary policy response to oil price shocks, while stock market returns will serve as a measure of the financial response to these shocks. We distinguish between net oil importing and net oil exporting countries.

It is worth noting that very little work has appeared with regard to monetary policy and oil prices for Russia, while at the same time most papers usually examine the effect of oil price shocks on the macroeconomic aggregates and not the effect on monetary policy.

The selection of countries satisfies three main concerns of the authors. Primarily this is a study related to European continent countries, which have not been extensively studied in the past. In addition, given that the sample consists of two net oil exporting countries (Norway and Russia) and four net oil importing countries (UK, France, Germany and Portugal), it allows for a thorough comparison of their financial and monetary responses to oil price shocks. Relatively little research has been conducted on the different effects of an oil price shock on the two aforementioned groups of countries (see, inter alia, Korhonen and Ledyaeva, 2010; Bjornland, 2009; Lescaroux and Mignon, 2008; JimenezRodriguez and Sanchez, 2005). Finally, there is a special focus of this study on possible diverse oil price effects between the traditional stock markets, such as UK, France and Germany and the newly established and/or less liquid stock markets, such as Russia, 
Norway and Portugal. Thus motivated, our study elucidates three important aspects which have not been extensively examined in the past.

The extensive literature has so far addressed several issues related to the impact of oil price innovations for member countries of the G7, OPEC and OECD (see, inter alia, Miller and Ratti, 2009; Cologni and Manera, 2008; Jimenez-Rodriguez and Sanchez, 2005). Prominent among these issues is the investigation of the effects of an oil price shock on various macroeconomic variables, such as GDP, consumer price index, interest rates, industrial production and unemployment.

Furthermore, authors such as Sadorsky (1999), Jones and Kaul (1996) and Haung, Masulis and Stoll (1996) investigate the relationship between oil prices and stock market returns. They all conclude that oil price changes are important determinants of stock market returns. Economic theory suggests that any asset price is determined by the expected discounted cash flows of that asset. Therefore, an oil price increase would inflate costs and profits would eventually decrease, undermining shareholders value. In this regard, stock prices will tend to decrease. However, the aforementioned studies do not examine whether the relationship between oil prices and stock market performance is different for oil-importing and oil-exporting countries.

The rest of the paper is organized as follows. In the next section, we briefly discuss the theory underpinning the transmission mechanisms among oil, inflation, interest rates, and the stock market. We then discuss existing work in the field under consideration, documenting the relationship between oil prices, the economy and stock markets. We then turn to a brief description of the Structural VAR model and the presentation of our 
dataset. Finally, empirical results are outlined and discussed, before a conclusion is reached.

\section{Theoretical context of transmission mechanisms}

In the case of an oil-exporting country, the effects of an oil price increase are expected to be positive, as initially, the income of this country is likely to increase (Bjornland, 2009; Jimenez-Rodriguez and Sanchez, 2005). Consequently, both consumption and investment are expected to rise in magnitude and this in turn will lead to an increase in the production of services and goods, as well as, to a contraction of unemployment. Stock markets are expected to rise as a result of a prosperous investing environment. This period of growth is likely to come to an end though, as demand-side inflation will eventually make its appearance (Bjornland, 2009; Jimenez-Rodriguez and Sanchez, 2005).

On the other hand, an oil-importing country immediately faces supply driven inflation in the case of a positive oil price shock and cost of production is expected to rise because oil, in its various forms, is one of the most basic inputs of production (Arouri and Nguyen, 2010; LeBlanc and Chinn, 2004; Hooker, 2002; Abel and Bernanke, 2001; Backus and Crucini, 2000; Kim and Loungani, 1992; Barro, 1984). Increased costs will be passed on to consumers, consumer prices will rise and this in turn will result in relatively low levels of aggregate demand; see, for example, Abel and Bernanke (2001), Hamilton (1996), Hamilton (1988) and Barro (1984).

Producers are likely to pass the increased cost of production to final consumption either by increasing product prices or by confining production itself. In any case, 
unemployment is expected to rise and consumption to fall (Lardic and Mignon, 2006; Brown and Yucel, 2002; Davis and Haltiwanger, 2001; Caruth, Hooker and Osward, 1998). Stock markets are expected to decline as a result of a negative investing environment (Sadorsky, 1999; Jones and Kaul, 1996; Haung et al, 1996). In short, this country may very well enter a period of economic downturn.

Eventually it all comes down to monetary policy (Bernanke, Gertler and Watson, 1997). Based on Taylor's rule (1993), an increase in the short term interest rates might be a suitable treatment for the demand-side inflation in an oil-exporting country. If the central bank decides to raise the short term interest rates, the expected confinement of consumption and investment will eventually restrain inflation. This rise, however, will negatively affect stock market performance. On the other hand, a decrease in the interest rates will probably be a suitable decision for the oil-importing country, providing demand stimulus. More specifically, we anticipate that the period of distress will come to an end, as investments and consumption become cheaper. Such a decision can have a positive effect on the stock market.

Although this may seem an obvious transmission mechanism, many argue that certain conditions must hold in order for the monetary policy to have the desirable effects. For example, Gali and Gerlter (2007) proponent that central bank's credibility is essential for the success of the monetary policy. Central bank's credibility is linked with the ability of the bank to manage private sector's expectations on future monetary policy decisions. In addition, Laopodis (2009) argues that the effects of monetary policy decisions on stock markets are stronger during bearish than bullish periods. However, Bjornland and 
Leitemo (2009) report a bidirectional rather than a unidirectional relationship between monetary policy and stock market performance.

It is also important not to lose sight of the fact that such monetary policy decisions will be made only by countries whose primary concern is to regulate inflation. Granville and Mallick (2006) suggest that only mature economies are trying to regulate inflation using interest rates. Other economies, mainly emerging, are trying to regulate their exchange rate fluctuations, instead.

On the other hand, Svensson (1999) voices the opinion that open economies can induce real exchange rate movements to affect inflation, via the aggregate demand channel for domestic goods. Such practice is expected to result in a quicker inflation response.

\section{Background of the Study}

\subsection{Oil price effect on the economy}

Mounting evidence suggests that oil prices have a strong influence on the economy. Various authors in the past have examined the effects of oil prices on industrial production and inflation, suggesting a negative effect on industrial production and a positive effect on inflation (see, inter alia, Tang, Wu and Zhang, 2010; Du, He and Wei, 2010; Miller and Ratti, 2009; Cologni and Manera, 2008; Ciner 2001; Haung et al, 1996; Ferderer, 1996; Gisser and Goodwin, 1986; Burbridge and Harrison, 1984; Hamilton, 1983). An increased oil price would inflate production costs, subsequently resulting in lower production and thus lower expected earnings (Jones, Lelby and Paik, 2004).

Jimenez-Rodriguez and Sanchez (2005) find that there is a bidirectional relationship between oil price movements and macroeconomic indicators, such as inflation. They also 
point out the different effect that oil prices exercise on oil-importing economies and oilexporting economies; suggesting that on one hand, an oil price increase could be beneficiary for the oil-exporting country whereas, on the other hand, it could be detrimental for the oil-importing country. Similar findings were presented by Mendoza and Vera (2010), Korhonen and Ledyaeva (2010), Bjornland (2009) and Lescaroux and Mignon (2008). Cunado and Perez de Gracia (2005) suggest that the effect of oil prices on macroeconomic indicators tends to be different when oil prices are converted in domestic currency rather than in dollar terms. Barsky and Kilian (2004), on the other hand, argue that an oil price shock does not necessarily lead to an immediate effect on the economy.

Other studies have shown, though, a structural break in the relationship between oil prices and macroeconomic indicators after the 1980s. More specifically, they suggest that oil price changes do not significantly affect inflation and thus they are not the main source for economic downturn, as Hamilton had suggested back in 1983. This structural break can be partly attributed to the recent trend in national monetary policy formulation being focused on the confrontation of inflationary pressures (Lescaroux and Mignon, 2008; Blanchard and Gali, 2007; Bernanke et al, 1997). The International Energy Agency (2006) argues that when in a state of economic growth, a country is not likely to face the negative impacts of an oil price increase, in respect to inflation. This is mainly due to the fact that increasing productivity and investment enable firms to absorb production input costs.

Through the lens of monetary policy response to oil price shocks, central banks are faced with a trade-off between inflation and output (Castillo, Montoro and Tuesta, 2010). 
Bernanke et al (1997) argue that a contractionary monetary policy is not necessarily the optimal solution, since it could aggravate the negative effects of these shocks. In particular, they suggest that the negative effects of oil price shocks that the US economy experienced during the period of late 70 s to early 90 s, should be mainly attributed to the monetary policy response of the Federal Reserve Bank, rather than to the oil price shock itself. Had the FED assumed a neutral response (i.e. no alteration of the funds rate) the output contraction would have been substantially less. This analysis is in line with an earlier study by Bohi (1989). However, Hamilton and Herrera (2004) argue that the relative contribution of monetary policy and oil price shocks to economic developments may not be as effective as Bernanke et al (1997) have suggested. In addition, Clarida, Gali and Gertler (2000), as well as, DeLong (1997) propose that different monetary policy rules could result in substantially different inflation responses to oil price shocks.

At the other end of the spectrum, considering that oil price shocks could be regarded as purely monetary shocks in nature, active monetary policy is then required not only to subdue inflationary pressures but also to ensure minimum contractionary effects on output (Castillo et al, 2010; Romer and Romer, 1989).

Jimenez-Rodriguez (2009) provides another angle on the relationship between oil prices and the economy. She argues that the effects of oil price shocks should be considered along with the economic environment at the time of the shock. Oil price shocks during stable economic periods would generate a higher impact on the economy compared to similar shocks during turbulent periods. 


\subsection{Oil price effect on the stock market}

Authors argue that oil prices could have both a direct and an indirect negative influence on the stock market performance. The direct effect can be explained by the fact that oil price shocks can be considered as a risk factor for financial markets and thus a positive oil price shock may induce a decrease in share prices (Jones and Kaul, 1996). On the other hand, an indirect negative effect can also be justified. Evidence from the previous section (section 3.1.) suggests that higher oil prices lead to higher inflation. Higher inflation rates can, in turn, cause a negative effect on the stock market.

This negative relationship between oil prices and stock returns has also been documented by Filis (2010), Chen (2009), Miller and Ratti (2009), Driesprong, Jacobsen and Maat (2008), Nandha and Faff (2008), O'Neill, Penm and Terrell (2008), Park and Ratti (2008), Bachmeier (2008), Ciner (2001) and Gjerde and Sættem (1999). Nandha and Brooks (2009) suggest that the effect of oil prices on stock market returns depends on the country's characteristics and the sector of the economy. Sadorsky (1999), who have also reached the same conclusion and suggest that apart from oil price changes, oil price volatility has an impact on stock returns, as well. Similar findings were reported by a recent paper by Malik and Ewing (2009), who also suggested that the oil price volatility causes negative effects on stock market returns. Oberndorfer (2009) seconds that opinion in his study of the effect of oil price volatility on European stock markets.

A slightly different approach is adopted by Haung et al (1996) who examine the relationship between oil future price returns and US stock returns. In agreement with Chen, Roll and Ross (1986), they provide evidence that oil future prices tend to influence oil companies' stock returns but not the overall market. 
All aforementioned studies mainly concern oil-importing countries. Pertaining to oilexporting countries, Arouri and Rault (2009) suggest that a positive oil price shock has a positive impact on the stock market performance. Similar results are documented by Bashar (2006). However, Al-Fayoumi (2009) finds no evidence that oil price shocks affect stock markets in oil-exporting countries.

Several studies focus on the origin of the oil price shock in order to understand and interpret the effects of oil price shocks on stock markets (see, inter alia, Hamilton, 2009a,b; Kilian, 2009; Lescaroux and Mignon, 2008; Barsky and Kilian, 2004; Terzian, 1985). Hamilton (2009a), for example, draws a distinction line between the sources of an oil price shock. According to him, an oil price shock could either originate from the industrialisation of countries such as China (demand-side shock) or from the lack of an immediate response of oil-supply to a large scale increase in oil-demand (supply-side shock). Kilian (2009), on the other hand, suggests that there are three sources of oil price shocks, namely, aggregate demand-side shock, precautionary demand-side shock and supply-side shock. Aggregate demand-side shocks occur due to global business cycle's fluctuations, precautionary demand shocks occur due to the uncertainty of future oil supply based on the expectations of future oil demand, and supply-side shocks are exogenous shocks and occur due to reduction of crude oil availability. Kilian and Park (2009) argue that demand-side oil price shocks influence stock prices more than the supply-side oil price shocks.

Kilian and Park (2007) show that demand driven shocks cause negative effects on US stock market returns. However, oil price increases, due to global economic expansion, tend to have a significant positive effect on stock returns. In the same line of reasoning, 
Hamilton (2009a) argues that demand-side shocks deriving from the industrialisation of countries such as China could have a significant positive impact on the stock markets. A quite different approach on the investigation of oil price effect on stock markets is followed by Filis, Degiannakis and Floros (2011) and Bharn and Nikolova (2010). In particular, these studies used measures of dynamic correlation between stock market and oil prices. They provide evidence of asymmetric behaviour of the correlation between stock market returns and oil price returns, which depends on the source of the oil price shock (i.e. demand-side shock or supply-side shock).

Contrary to the above, part of the literature suggests that there is no relationship between oil price innovations and stock markets (see, inter alia, Jammazi and Aloui, 2010; Apergis and Miller, 2009; Cong, Wei, Jiao and Fan, 2008).

It should also be noted that the majority of these studies do not include both oil-importing and oil-exporting countries in their sample. Thus the current research bridges this gap by including both oil-importing and oil-exporting countries in the sample.

\section{Methodology and Data Description}

\subsection{Methodology}

We examine the dynamic relationship among the growth rates of oil prices (OIL), the consumer price index (INF), interest rates (INT) and stock market index (IND), in two net oil-exporting countries (Norway and Russia) and four net oil-importing countries (UK, Germany, France and Portugal), by employing a Structural VAR model, separately for each country. We also investigate the transmission mechanism of stochastic shocks of these series. 
The structural representation of the VAR model of order $p$ takes the following general form:

$$
A_{0} y_{t}=c_{0}+\sum_{i=1}^{p} A_{i} y_{t-i}+\varepsilon_{t}
$$

where $\mathbf{y}_{t}$ is a $\mathrm{m} \times 1$ vector of endogenous variables, $A_{i}$ are $\mathrm{m} \times \mathrm{m}$ autoregressive coefficient matrices, $\varepsilon_{\mathrm{t}}$ is an $\mathrm{m} \times 1$ vector of structural disturbances, assumed to have zero covariance and be serially uncorrelated. $A_{0}$ is a $\mathrm{m} \times \mathrm{m}$ matrix containing the contemporaneous relations among the variables. In order to get the reduce form of model (1) we multiply both sides of the equation with $A_{0}^{-1}$. Let $\mathrm{e}_{\mathrm{t}}$ be the reduced form errors, where $e_{t}=A_{0}^{-1} \varepsilon_{t}$, assumed to be white noise processes. The structural disturbances can be derived by imposing suitable restrictions on $A_{0}$. With reference to section 2 we impose the following exclusion restrictions in our model:

$$
\left[\begin{array}{l}
e_{1 t}^{\text {OIL }} \\
e_{2 t}^{I N F} \\
e_{3 t}^{I N T} \\
e_{4 t}^{I N D}
\end{array}\right]=\left[\begin{array}{cccc}
a_{11} & 0 & 0 & 0 \\
a_{21} & a_{22} & 0 & 0 \\
a_{31} & a_{32} & a_{33} & 0 \\
a_{41} & a_{42} & a_{43} & a_{44}
\end{array}\right] \times\left[\begin{array}{l}
\varepsilon_{1 t}^{\text {OIL Shock }} \\
\varepsilon_{2 t}^{I N F} \text { Shock } \\
\varepsilon_{3 t}^{I N T} \text { Shock } \\
\varepsilon_{4 t}^{I N D} \text { shock }
\end{array}\right]
$$

To proceed to the estimation of the reduced form of model (1), it is first necessary to establish the stationarity of the variables. The ADF and PP unit root tests with intercept only and trend and intercept suggest that all variables are $\mathrm{I}(0)^{1}$. The order of each model was identified using the Akaike Information Criterion ${ }^{2}$. For almost all countries (UK, France, Germany and Russia) the AIC suggested a VAR model of order 6. For the rest of

\footnotetext{
${ }^{1}$ Results can be obtained upon request.

${ }^{2}$ Results can be obtained upon request.
} 
the countries (Portugal and Norway) the lag-length that was suggested by AIC was 5. In this regard, we have decided to use six lags for all countries.

\subsection{Data Description}

We use monthly data from 1991:01 to 2010:04 for UK, France, Germany and Norway. For Russia the data used are from 1996:04 to $2010: 04^{3}$ and for Portugal from 1995:02 to 2010:04 ${ }^{4}$. The stock market indices used are the SBF120 (France), DAX 30 (Germany), PS120 (Portugal), FTSE100 (UK), RTS (Russia) and OBX 25 (Norway). We also take each country's CPI, which is seasonally adjusted with the same base year (2000). The interest rates used in this study are the 1-month interbank rates of each country. For oil we use the Brent crude oil prices, converted in local currency. Brent crude oil was chosen, as a proxy of world oil price, due to the fact that this type of oil represents the $60 \%$ of the world oil daily consumption (Maghyereh, 2004). We convert oil prices into real oil prices by taking into consideration the exchange rate between the currency ${ }^{5}$ of each country and the dollar over the period of study and the consumer price indices. Interest rates and stock market prices are expressed in real terms, as well, taking into consideration the corresponding CPI index.

The stock market prices and interest rates were collected from Datastream ${ }^{\circledR}$, consumer price indices were collected from the Eurostat and the national statistical services of the selected countries and oil prices in dollar terms were extracted from Energy Information Administration. All variables are expressed in logarithms.

\footnotetext{
${ }^{3}$ We do not consider any available data prior to 1996 , as during this time Russia was in a transition period, which was characterised by a volatile behaviour of the variables under consideration. This is in line with Granville and Mallick (2010).

${ }^{4}$ Data availability issues have imposed constraints to our sample period.

${ }^{5}$ Exchange rates were collected from Pacific Exchange Rate Service.
} 


\title{
5. Empirical Results and Discussion
}

\subsection{Preliminary Tests}

Table 1 reports the descriptive statistics of the series. It can be observed that OIL is showing the higher amplitude on all countries except Russia, whose stock market (IND) and interest rates (INT) exhibit greater volatility than oil prices. This is mainly due to the fact that Russia has a newly established stock market. CPI exhibits the lowest amplitude on all countries. Furthermore, we can observe that the INT is negative on all countries, which shows the declining nature of interest rates during the period under consideration in this study.

\section{[TABLE 1 HERE]}

\begin{abstract}
All variables have a mean very close to zero. However, there is an indication of nonnormally distributed series, as J-B statistic is significant in all cases. This is probably due to non-linearities involved in the growth rate fluctuations. This non-normality is also evident from the kurtosis and skewness coefficients.
\end{abstract}

\subsection{Structural VAR results - Impulse Response Functions}

The purpose of the VAR-family models (including the SVAR framework) is mainly to examine the dynamic adjustments of each of the involved variables to exogenous stochastic structural shocks (see, inter alia, Bjornland and Leitemo, 2009; Kilian and 
Park, 2009; Papapetrou, 2001; Burbridge and Harrison, 1984). Thus, as space is limited, we only present the analysis of the impulse response functions ${ }^{6}$.

\section{[FIGURE 1]}

\section{[TABLE 2]}

Starting from the net oil-importing countries; a positive oil price shock in Germany results in an immediate positive response of inflation. This effect decreases over time, until it becomes negligible 10 months later. However, since the forth month after the oil price shock, the response of inflation is at a minimum. The interest rates react immediately and positively to the inflationary pressure. On the other hand, the interest rates react positively to the oil price increase with one month delay. This delay can be attributed to the time that is required for an oil price shock to propagate its effects to the economy. The stock market initially has a negative response to the oil price shock, oscillating negatively for a period of 8 months before starting to fade out. In addition, inflation and interest rates seem to exercise a negative impact on the stock market, as these are depicted by the impulse response functions. Kaul and Seyhun (1990) proponent that the effect of inflation on stock market performance could be triggered by output shocks caused by disturbances in crude oil prices. Past studies have also documented these relationships (see, inter alia, Miller and Ratti, 2009; Nandha and Faff, 2008; Park and Ratti, 2008 for the effect of oil prices on the stock market; Cologni and Manera, 2008; Omrana, 2003; Flannery and Protopapadakis, 2002 for the effect of inflation on the stock market). The same pattern can also be observed in all remaining net oil-exporting countries, namely France, UK and Portugal. Our results are in line with economic theory,

\footnotetext{
${ }^{6}$ The actual VAR(6) coefficient tables are available upon request.
} 
in the sense that such developments are expected in countries that employ an inflation targeting monetary policy rule.

However, particularly for UK and Portugal, we notice that it takes two months for the positive response of inflation to the oil price shock to reach a peak, before it eventually exhibits a decreasing pace. Hence, we can argue that the oil price shock is more persistent in UK and Portugal, as opposed to France and Germany. France and Germany exhibit their potential to battle inflationary pressures (due to oil price increases) immediately, whereas delays are observed in UK and Portugal.

Turning to the net oil-exporting countries; a positive oil price shock in Russia causes a positive response of inflation; a response which is immediate and of high magnitude, suggesting demand-side inflation (see, inter alia, Bjornland, 2009; LeBlanc and Chinn, 2004; Hooker 2002). The effect of oil price increases on inflation disappears rapidly (one to two months later) and eventually becomes negligible eight months after the shock. Furthermore, an immediate and negative response of interest rates to a positive oil price shock can be reported. Interest rates respond negatively and immediately on inflationary pressures, as well. Admittedly, these results lack theoretical flavour in the sense that they are not supported by any prevailing economic argument. Nonetheless, a possible explanation of these responses could be found in the monetary policy targeting that Russia is engaged with. In particular, Russia's monetary policy is not inflation targeting; instead, it has an exchange rate targeting regime. Increased oil prices trigger immediate transfer of wealth to Russia from foreign countries. This, in turn, results in lower interest rates, due to the increased availability of money in the economy. To further our analysis regarding Russia, its stock market initially responds negatively to the positive oil price 
shock; this response, however, becomes positive from the second month onwards and eventually dies out completely in about two years time. In addition, stock market responds negatively to both inflation and interest rates shocks. The negative relationship that runs from inflation to the stock market, suggests that high inflation leads the stock market to lower levels. Similar conclusions were presented in other studies, such as Omrana (2003), Flannery and Protopapadakis (2002) and Siklos and Kwok (1999).

As far as Norway is concerned, a positive oil price shock causes a positive response from inflation which is rather low in magnitude and eventually becomes negligible three months later. Furthermore, we cannot identify any significant effect of oil on interest rates at least not until four months have passed. Interest rates though, respond immediately and positively to inflationary pressures and a peak is reached by the seventh month. The magnitude of this response, however, is rather low. Finally, on one hand, we have a positive impact of the oil price shock on the stock market (similarly with Bjornland, 2009; Jimenez-Rodriguez and Sanchez, 2005), whereas, on the other hand, the stock market reacts negatively on inflationary pressures and interest rates developments.

Overall, we find evidence suggesting that oil prices affect the level of inflation in both net oil-exporting and net oil-importing countries, which is in contrast to what Hamilton (2008), Lescaroux and Mignon (2008) and Blanchard and Gali (2007) have suggested, i.e. that from 1980s onwards inflationary pressures cannot be attributed to oil price increases, since the importance of oil, as a production input, gradually decreases.

Furthermore, we find that the response of interest rates to an oil price shock depends heavily on the monetary policy regime of each country. We observe that countries with 
inflation targeting regime, exhibit an inclination towards restricting inflationary pressures (due to oil price increases) by immediately increasing interest rates.

On general principles, stock markets exhibit a negative response to increased oil prices. The only exception is the Norwegian stock market, an exception somewhat expected, as Norway is a net oil-exporter.

Finally, our results distinguish between responses of traditional and newly established and/or thin stock markets in oil price shocks. In particular, it is evident that the magnitude of stock market responses to oil price shocks is higher for the newly established and/or thin stock markets (such as Russia and Norway). This finding can be attributed to the fact that thin stock markets tend to overestimate the workings of economic activity.

\section{Conclusion}

In this study, we investigate the financial and monetary policy responses to oil price changes in six countries, namely UK, Norway, Russia, Germany, France and Portugal; corresponding to two net oil-exporting countries (Norway and Russia) and four net oilimporting countries (Germany, France, UK and Portugal).

Overall, we find evidence suggesting that the level of inflation in both net oil-exporting and net oil-importing countries is affected by oil prices. A finding which poses a contradiction to what Hamilton (2008), Lescaroux and Mignon (2008) and Blanchard and Gali (2007) have suggested, i.e. that from 1980s onwards inflationary pressures cannot be attributed to oil price increases. Furthermore, we find that the response of interest rates to an oil price shock depends heavily on the monetary policy regime of each country. In addition, stock markets exhibit a negative response to increased oil prices. The only 
exception is the Norwegian stock market, which is somewhat expected, as Norway is a net oil-exporting country.

Finally, our results distinguish between responses of traditional and newly established and/or thin stock markets to oil price shocks. In particular, it is evident that the magnitude of stock market responses to oil price shocks is higher for the newly established and/or less liquid stock markets (such as Russia and Norway). This can be attributed to the fact that these stock markets tend to overestimate the workings of real economic activity.

Further research in the field should incorporate the origin of an oil price shock; that is whether it comes from the supply-side or the demand-side. Finally, further study could examine the asymmetric effects of oil prices on monetary policy and stock market responses. 


\section{References}

Abel, A.B., Bernanke, B.S., 2001. Macroeconomics. Addison Wesley Longman Inc.

Al-Fayoumi, A.N., 2009. Oil prices and stock market returns in oil importing countries: The case of Turkey, Tunisia and Jordan. European Journal of Economics, Finance and Administrative Sciences 16, 86-101.

Apergis, N., Miller S., 2009. Do structural oil - market shocks affect stock prices?. Energy Economics 31, 569-575.

Arouri, M.E.H., Nguyen, K.D., 2010. Oil prices, stock markets and portfolio investment: Evidence from sector analysis in Europe over the last decade. Energy Policy, 38, 4528-4539.

Arouri, M.E.H., Rault, C., 2009. On the influence of oil prices on stock markets: Evidence from panel analysis in GCC countries. William Davidson Institute Working Papers Series with number wp961.

Bachmeier, L., 2008. Monetary policy and the transmission of oil shocks. Journal of Macroeconomics 30, 1738-1755.

Backus, D.K., Crucini, M.J., 2000. Oil prices and the terms of trade. Journal of International Economics 50, 185-213.

Barro, R.J., 1984. Macroeconomics. John Wiley \& Sons.

Barsky, R.B., Kilian, L., 2004. Oil and the macroeconomy since the 1970s. Journal of Economic Perspectives 18, 115-134.

Bashar, A.Z., 2006. Wild oil prices, but brave stock markets! The case of GCC stock markets. Operational Research 6, 145-162. 
Bernanke, B.S., Gertler, M., Watson, M., 1997. Systematic monetary policy and the effects of oil price shocks. Brookings Papers on Economic Activity 1, 91-148.

Bharn, R., Nikolovann, B., 2010. Global oil prices, oil industry and equity returns: Russian experience. Scottish Journal of Political Economy 57, 169-186.

Blanchard, O. Gali J., 2007. The macroeconomic effects of oil price shocks. Why are the 2000s so different than the 1970s? National Bureau of Economic Research Working Paper 13368.

Bjornland, H.C., 2009. Oil price shocks and stock market booms in an oil exporting country. Scottish Journal of Political Economy 2, 232-254.

Bjornland, H.C., Leitemo, K. 2009. Identifying the interdependence between US monetary policy and the stock market. Journal of Monetary Economics 56, 275282.

Bohi, D.R., 1989. Energy price shocks and macroeconomic performance. Resources for the Future, Washington, D.C.

Brown, S.P.A., Yücel, M.K., 2002. Energy prices and aggregate economic activity: An interpretative survey. Quarterly Review of Economics and Finance 42, 193-208.

Burbridge, J., Harrison, A., 1984. Testing for the effects of oil price rises using vector autoregressions. International Economic Review 25, 459-484.

Caruth, A., Hooker, M.A., Oswald, A.J., 1998. Unemployment equilibria and input prices: Theory and evidence from the United States. Review of Economics and Statistics 80, 621-628.

Castillo, P.M., Vicente. C.T., 2010. Inflation, oil price volatility and monetary policy. Banco Central de Reserva del Perú Working Papers 2010-002. 
Chen, N.F., Roll, R., Ross, S., 1986. Economic forces and the stock market. Journal of Business 59, 383-403.

Chen, S.S., 2010. Do higher oil prices push the stock market into bear territory? Energy Economics 32, 490-495.

Ciner, C., 2001. Energy shocks and financial markets: Nonlinear linkages. Studies in Nonlinear Dynamics and Econometrics 5, 203-212.

Clarida, R., Gali, J., Gertler, M., 2000. Monetary policy rules and macroeconomic stability: Evidence and some theory. Quarterly Journal of Economics 115, 147-180.

Cologni, A., Manera, M., 2008. Oil prices, inflation and interest rates in a structural cointegrated VAR model for the G-7 countries. Energy Economics 30, 856-888.

Cong, R.G., Wei, Y.M., Jiao, J.L., Fan, Y., 2008. Relationships between oil price shocks and stock market: An empirical analysis from China. Energy Policy 36, 3544-3553.

Cunado, J., Perez de Gracia, F., 2005. Oil prices, economic activity and inflation: Evidence for some Asian countries. The Quarterly Review of Economics and Finance 45, 65-83.

Davis, S.J., Haltiwanger, J., 2001. Sectoral job creation and destruction responses to oil price changes. Journal of Monetary Economics 48, 645-512.

DeLong, J. B., 1997. America's Peacetime Inflation: The 1970s in C. Romer and D. Romer, eds., Reducing Inflation: Motivation and Strategy, Chicago: Chicago University Press.

Driesprong, G., Jacobsen, B., Maat, B., 2008. Striking oil: Another puzzle? Journal of Financial Economics, 89, 307-327. 
Du, L., He, Y., Wei, C., 2010. The relationship between oil price shocks and China's macro-economy: An empirical analysis. Energy Policy 38, 4142-4151.

Ferderer, P.J., 1996. Oil price volatility and the macroeconomy. Journal of Macroeconomics 18, 1-26.

Filis, G., 2010. Macro economy, stock market and oil prices: Do meaningful relationships exist among their cyclical fluctuations? Energy Economics, 32, 877-886.

Filis, G., Degiannakis, S., Floros, C. 2011. Dynamic correlation between stock market and oil prices: The case of oil-importing and oil-exporting countries. International Review of Financial Analysis, in press.

Flannery, M.J., Protopapadakis, A., 2002. Macroeconomic factors do influence aggregate stock returns. The Review of Financial Studies 15, 751-81.

Gali, J., Gertler, M., 2007. Macroeconomic modeling for monetary policy evaluation. Journal of Economic Perspectives 21, 25-45.

Gjerde, Ø., Sættem, F., 1999. Causal relations among stock returns and macroeconomic variables in a small, open Economy. Journal of International Financial Markets, Institutions and Money 9, 61-74.

Granville, B.E., Mallick, S., 2006. Does inflation or currency depreciation drive monetary policy in Russia? Research in International Business and Finance 20, 163-179.

Granville, B.E., Mallick, S., 2010. Monetary policy in Russia: Identifying exchange rate shocks. Economic Modelling 27(1), 432-444.

Hamilton, J.D., 1983. Oil and the macroeconomy since World War II. The Journal of Political Economy 9, 228-248. 
Hamilton, J.D., 1988. Are the macroeconomic effects of oil-price changes symmetric? A comment. Carnegie-Rochester Conference Series on Public Policy 28, 369-378.

Hamilton, J.D., 1996. This is what happened to the oil price-macroeconomy relationship. Journal of Monetary Economics, 38, 215-220.

Hamilton, J.D., 2008. Understanding crude oil prices. National Bureau of Economic Research, Working Paper 14492.

Hamilton, J.D., 2009a. Understanding crude oil prices. Energy Journal 30, 179-206.

Hamilton, J.D., 2009b. Causes and consequences of the oil shock of 2007-08. Brookings Papers on Economic Activity Spring 2009, 215-261.

Hamilton, J.D., Herrera, A. M., 2004. Oil shocks and aggregate macroeconomic behavior: the role of monetary policy. Journal of Money, Credit and Banking 36, $265-286$.

Haung, R.D., Masulis, R.W., Stoll, H.R., 1996. Energy shocks and financial markets. Journal of Futures Markets 16, 1-27.

Hooker, M.A., 2002. Are oil shocks inflationary? Asymmetric and nonlinear specifications versus changes in regime. Journal of Money, Credit and Banking 34, $540-561$.

International Energy Agency. 2006. World energy outlook.

Jammazi, R., Aloui, C., 2010. Wavelet decomposition and regime shifts: Assessing the effects of crude oil shocks on stock market returns. Energy Policy 38, 1415-1435.

Jimenez-Rodriguez, R., Sanchez, M., 2005. Oil price shocks and real GDP growth: Empirical evidence for some OECD countries. European Central Bank, Working Paper No 362. 
Jimenez-Rodriguez, R., 2009. Oil price shocks and real GDP growth: Testing for nonlinearity. Energy Journal 30, 1-24.

Jones, C.M., Kaul, G., 1996. Oil and stock markets. Journal of Finance 51, 463-491.

Jones, D.W., Lelby, P.N, Paik, I.K., 2004. Oil price shocks and the macroeconomy: What has been learned since 1996. Energy Journal 25, 1-32.

Kaul, G., Seyhun, H.S., 1990. Relative price variability, real shocks and the stocks market. Journal of Finance 45, 479-496.

Kilian, L., Park, C., 2007. The impact of oil price shocks on the U.S. stock market. C.E.P.R. Discussion Papers, Working Paper 6166. http://www.cepr.org/pubs/dps/DP6166.asp. [accessed 12/7/2009]

Kilian, L., 2009. Not all oil price shocks are alike: Disentangling demand and supply shocks in the crude oil market. American Economic Review 99, 1053-1069.

Kilian, L., Park, C., 2009. The impact of oil price shocks on the U.S. stock market. International Economic Review 50, 1267-1287.

Kim, In-Moo, Loungani, Prakash, 1992. The role of energy in real business cycle models. Journal of Monetary Economics 29, 173-189.

Korhonen, I., Ledyaeva, S., 2010. Trade linkages and macroeconomic effects of the price of oil, Energy Economics 32, 848-856.

Laopodis, N. 2009. Dynamic linkages between monetary policy and the stock market. Review of Quantitative Finance and Accounting 35, 271-293.

Lardic, S., Mignon, V., 2006. Oil prices and economic activity: An asymmetric cointegration approach. Energy Economics 34, 3910-3915. 
Lescaroux, F., Mignon, V., 2008. On the influence of oil prices on economic activity and other macroeconomic and financial variables. Centre d' Etudes Prospectives et d' Information Internationales, No 2008-05.

LeBlanc, M., Chinn, M.D., 2004. Do high oil prices presage inflation? The evidence from G5 countries. Business Economics 34, 38-48.

Maghyereh, A., 2004. Oil price shocks and emerging stock markets. A generalized VAR approach. International Journal of Applied Econometrics and Quantitative Studies $1,27-40$.

Malik, F., Ewing, B., 2009. Volatility transmission between oil prices and equity sector returns. International Review of Financial Analysis 18, 95-100.

Mendoza, O., Vera, D., 2010. The asymmetric effects of oil shocks on an oil-exporting economy, Cuadernos de Economia, 47, 3-13

Miller, I.J., Ratti, R.A., 2009. Crude oil and stock markets: Stability, instability, and bubbles. Energy Economics 31, 559-568.

Nandha, M., Brooks, R. 2009. Oil prices and transport sector returns: an international analysis. Review of Quantitative Finance and Accounting 33, 393-409.

Nandha, M., Faff, R., 2008. Does oil move equity prices? A global view. Energy Economics 30, 986-997.

Oberndorfer, U., 2009. Energy prices, volatility, and the stock market: Evidence from the Eurozone. Energy Policy 37, 5787-5795.

Omrana, M., 2003. Time series analysis of the impact of real interest rates on stock market activity and liquidity in Egypt: Co-integration and error correction model approach. International Journal of Business 8 . 
http://papers.ssrn.com/sol3/papers.cfm?abstract_id=420248 [accessed 23/6/2009]

O'Neill, T.J., Penm, J., Terrell, R.D., 2008. The role of higher oil prices: A case of major developed countries. Research in Finance 24, 287-299.

Papapetrou, E., 2001. Oil price shocks, stock market, economic activity and employment in Greece. Energy Economics 23, 511-532.

Park, J., Ratti, R.A., 2008. Oil prices and stock markets in the U.S. and 13 European countries. Energy Economics 30, 2587-2608.

Romer, C.D., Romer, D.H., 1989. Does monetary policy matter? A new test in the spirit of Friedman and Schwartz. University of California at Berkeley Economics Working Papers 89-107.

Sadorsky, P., 1999. Oil price shocks and stock market activity. Energy Economics 21, 449-469.

Siklos, P., Kwok, B., 1999. Stock returns and inflation: A new test of competing hypotheses. Applied Financial Economics 9, 567-81.

Svensson, L.E.O., 1999. Inflation targeting as a monetary policy rule. Journal of Monetary Economics 43, 607-654.

Tang, W., Wu, L., Zhang, Z.X., 2010. Oil price shocks and their short- and long-term effects on the Chinese economy. Energy Economics 32, S3-S14.

Taylor, J.B., 1993. Discretion versus policy rules in practice. Carnegie-Rochester Conference Series on Public Policy 39, 195-214.

Terzian, P., 1985. OPEC The Insider Story. London: Zed Books 


\section{Tables}

Table 1: Descriptive statistics for oil prices, inflation, interest rates and stock market

\begin{tabular}{|c|c|c|c|c|c|c|}
\hline & $\underline{\text { Series }}$ & Mean & St. Dev. & $\underline{\text { Skewness }}$ & $\underline{\text { Kurtosis }}$ & J-B Stat. \\
\hline \multirow{4}{*}{ UK } & OIL & 0.002 & 0.004 & 1.209 & 12.721 & $948.959 *$ \\
\hline & INF & 0.004 & 0.043 & -0.731 & 5.523 & $80.417 *$ \\
\hline & INT & 0.006 & 0.106 & -0.045 & 3.938 & $8.413^{*}$ \\
\hline & IND & -0.014 & 0.059 & -2.915 & 16.840 & $2170.882^{*}$ \\
\hline \multirow[t]{4}{*}{ France } & OIL & 0.001 & 0.001 & 0.446 & 4.314 & $23.867 *$ \\
\hline & INF & 0.004 & 0.059 & -0.765 & 5.591 & $85.623 *$ \\
\hline & INT & 0.007 & 0.104 & -0.195 & 4.201 & $15.101 *$ \\
\hline & IND & -0.011 & 0.084 & 0.643 & 13.468 & $1070.758^{*}$ \\
\hline \multirow[t]{4}{*}{ Germany } & OIL & 0.001 & 0.002 & 0.252 & 15.254 & $1422.681 *$ \\
\hline & INF & 0.005 & 0.065 & -1.064 & 7.454 & $230.191 *$ \\
\hline & INT & 0.006 & 0.104 & -0.173 & 4.194 & $14.636^{*}$ \\
\hline & IND & -0.012 & 0.064 & -1.711 & 9.904 & $571.665^{*}$ \\
\hline \multirow[t]{4}{*}{ Norway } & OIL & 0.001 & 0.004 & 0.637 & 7.037 & $114.292 *$ \\
\hline & INF & 0.011 & 0.061 & -0.867 & 3.969 & $25.186^{*}$ \\
\hline & INT & 0.010 & 0.102 & -0.382 & 3.896 & $8.857 *$ \\
\hline & IND & -0.007 & 0.086 & -0.461 & 8.441 & $293.237^{*}$ \\
\hline \multirow[t]{4}{*}{ Portugal } & OIL & 0.002 & 0.003 & 0.434 & 3.712 & $9.883^{*}$ \\
\hline & INF & 0.007 & 0.056 & -0.202 & 3.734 & $5.569^{*}$ \\
\hline & INT & 0.008 & 0.101 & -0.359 & 4.103 & $13.742 *$ \\
\hline & IND & -0.016 & 0.071 & -1.547 & 9.091 & $356.009 *$ \\
\hline \multirow[t]{4}{*}{ Russia } & OIL & -0.001 & 0.033 & 0.375 & 66.294 & $2242.971^{*}$ \\
\hline & INF & 0.021 & 0.139 & -0.807 & 5.635 & $60.741 *$ \\
\hline & INT & 0.024 & 0.127 & 1.183 & 9.717 & $323.433 *$ \\
\hline & IND & -0.012 & 0.207 & 1.126 & 5.219 & $71.265^{*}$ \\
\hline
\end{tabular}

* significant at 5\% level. 
Table 2: Structural VAR model: Impulse Response Functions (time required for the shock to be absorbed)

\begin{tabular}{|c|c|c|c|c|c|c|c|}
\hline & & UK & France & Germany & Norway & Portugal & Russia \\
\hline \multirow[t]{4}{*}{ Response of OIL to shocks from } & OIL & 24 & 26 & 22 & 25 & 36 & 23 \\
\hline & INF & 26 & 30 & 25 & 26 & 34 & 22 \\
\hline & INT & 25 & 27 & 23 & 22 & 32 & 20 \\
\hline & IND & 16 & 26 & 27 & 26 & 41 & 19 \\
\hline \multirow[t]{4}{*}{ Response of INF to shocks from } & OIL & 22 & 25 & 25 & 30 & 41 & 25 \\
\hline & INF & 32 & 30 & 29 & 31 & 47 & 26 \\
\hline & INT & 28 & 26 & 31 & 27 & 38 & 21 \\
\hline & IND & 27 & 21 & 30 & 32 & 40 & 26 \\
\hline \multirow[t]{4}{*}{ Response of INT to shocks from } & OIL & 23 & 27 & 19 & 30 & 35 & 25 \\
\hline & INF & 20 & 34 & 25 & 32 & 32 & 26 \\
\hline & INT & 24 & 22 & 22 & 29 & 33 & 24 \\
\hline & IND & 26 & 18 & 24 & 31 & 38 & 26 \\
\hline \multirow[t]{4}{*}{ Response of IND to shocks from } & OIL & 18 & 27 & 22 & 25 & 37 & 20 \\
\hline & INF & 21 & 32 & 16 & 23 & 31 & 22 \\
\hline & INT & 16 & 31 & 19 & 26 & 34 & 21 \\
\hline & IND & 18 & 24 & 24 & 26 & 30 & 22 \\
\hline
\end{tabular}




\section{Figure}

Figure 1: Structural VAR model: Impulse Response Functions

\section{UK}
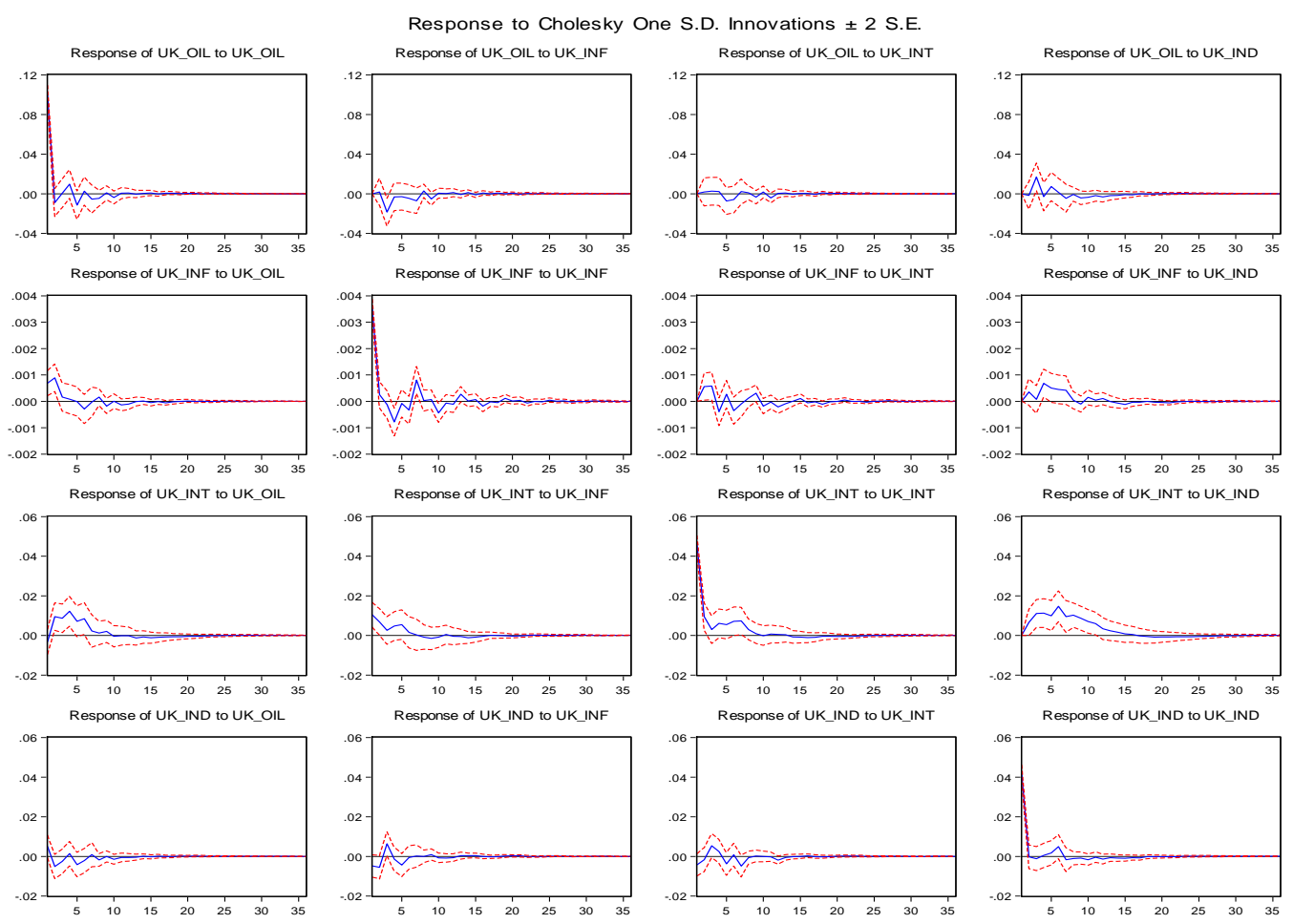

\section{France}
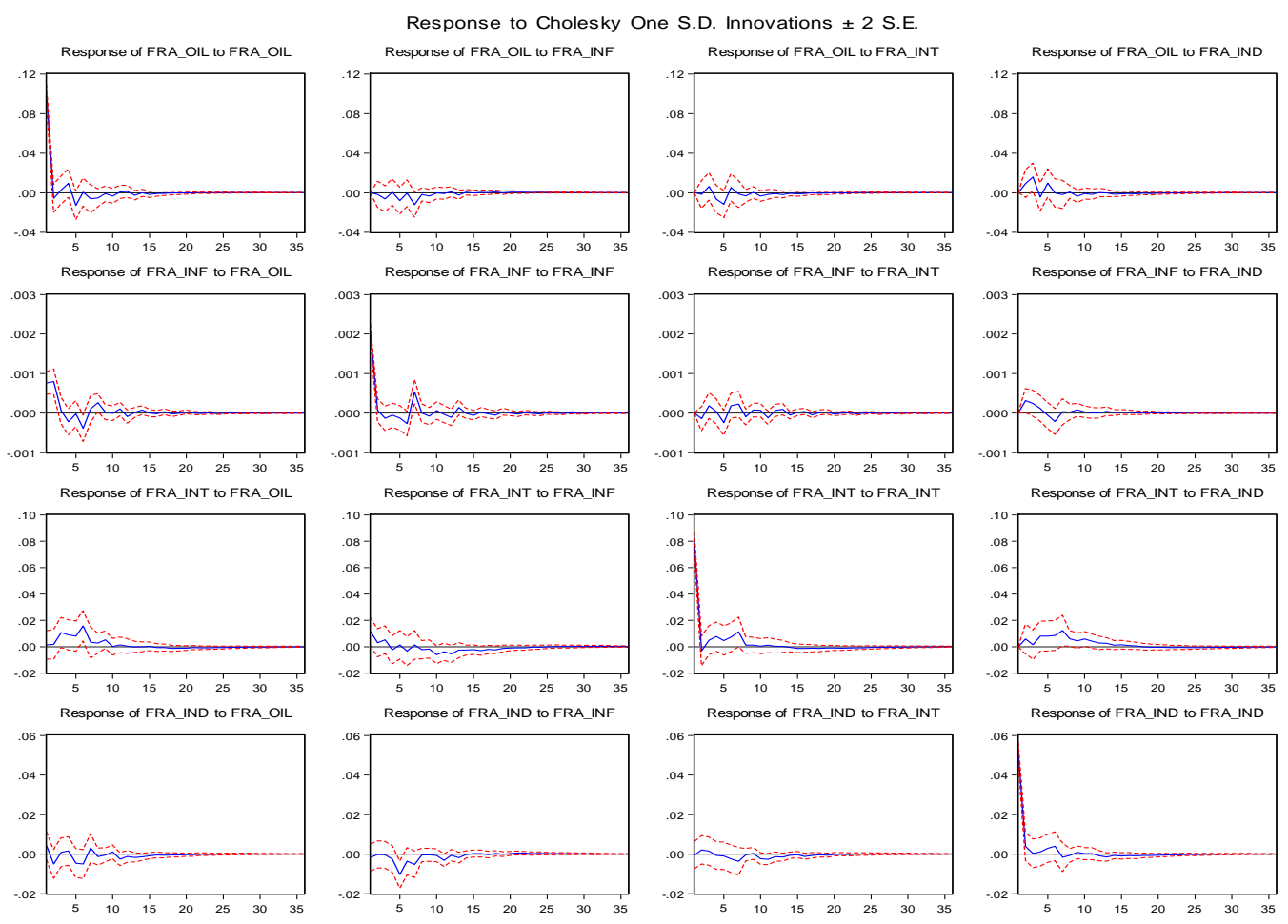


\section{Germany}
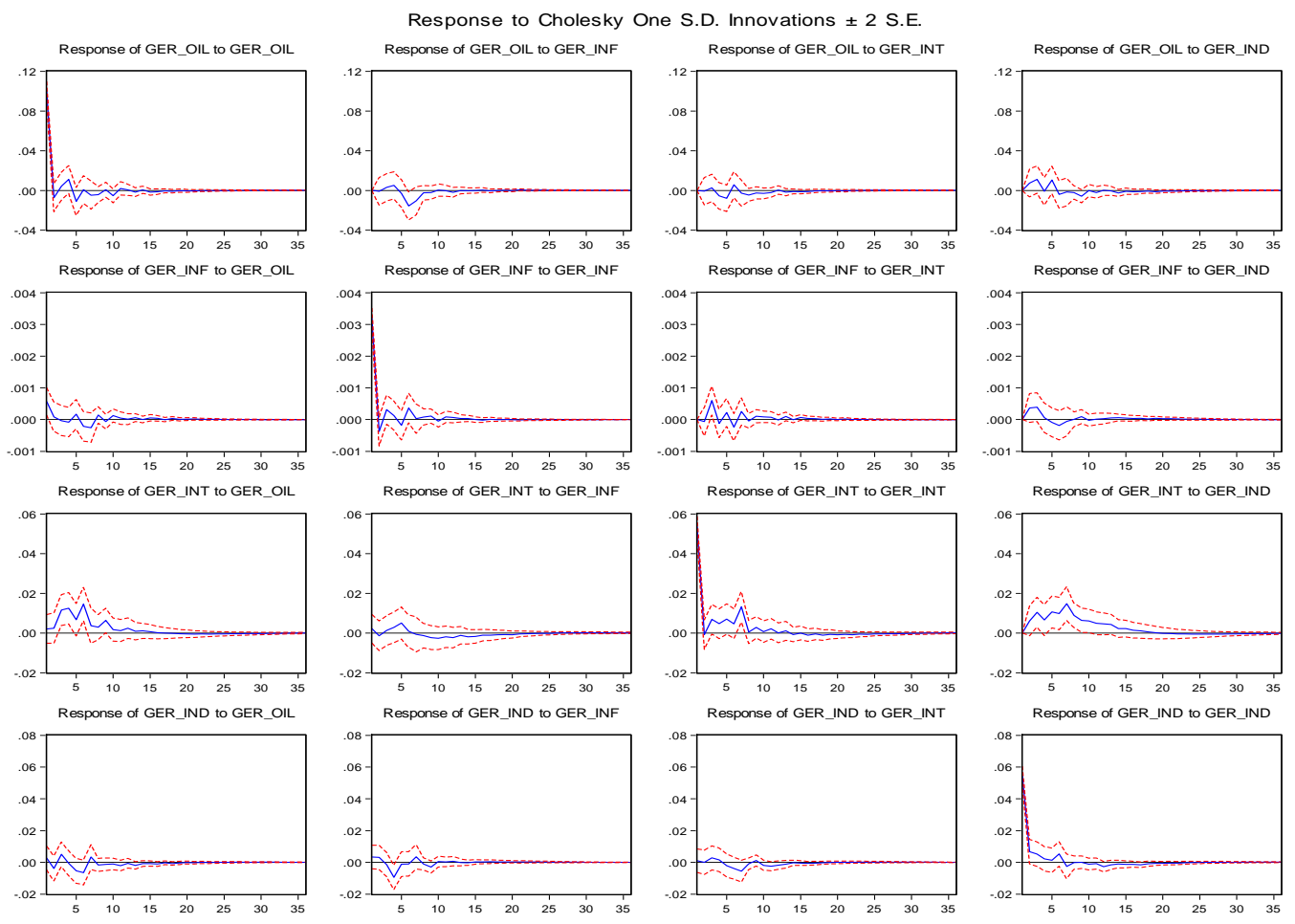

\section{Norway}
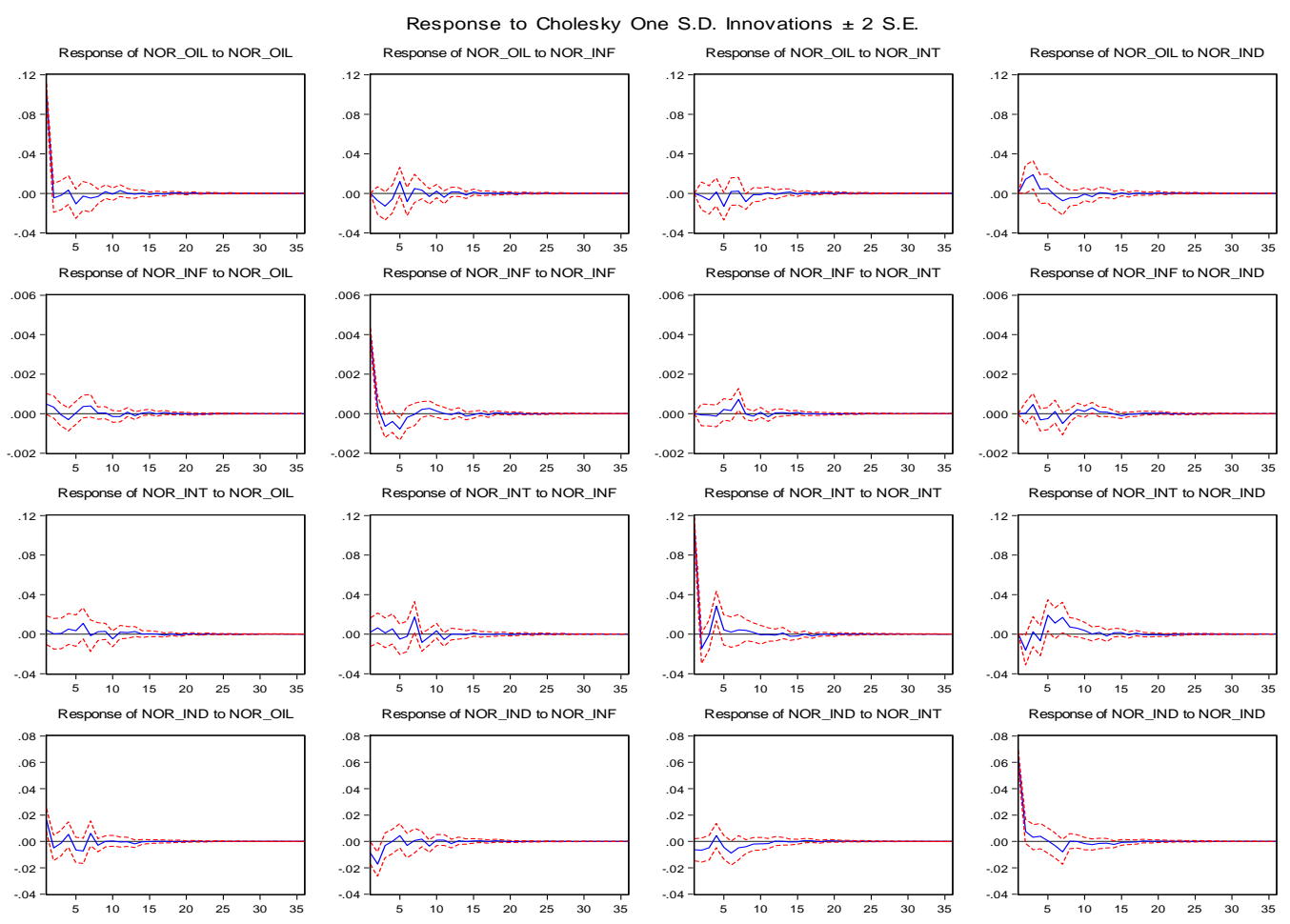


\section{Portugal}
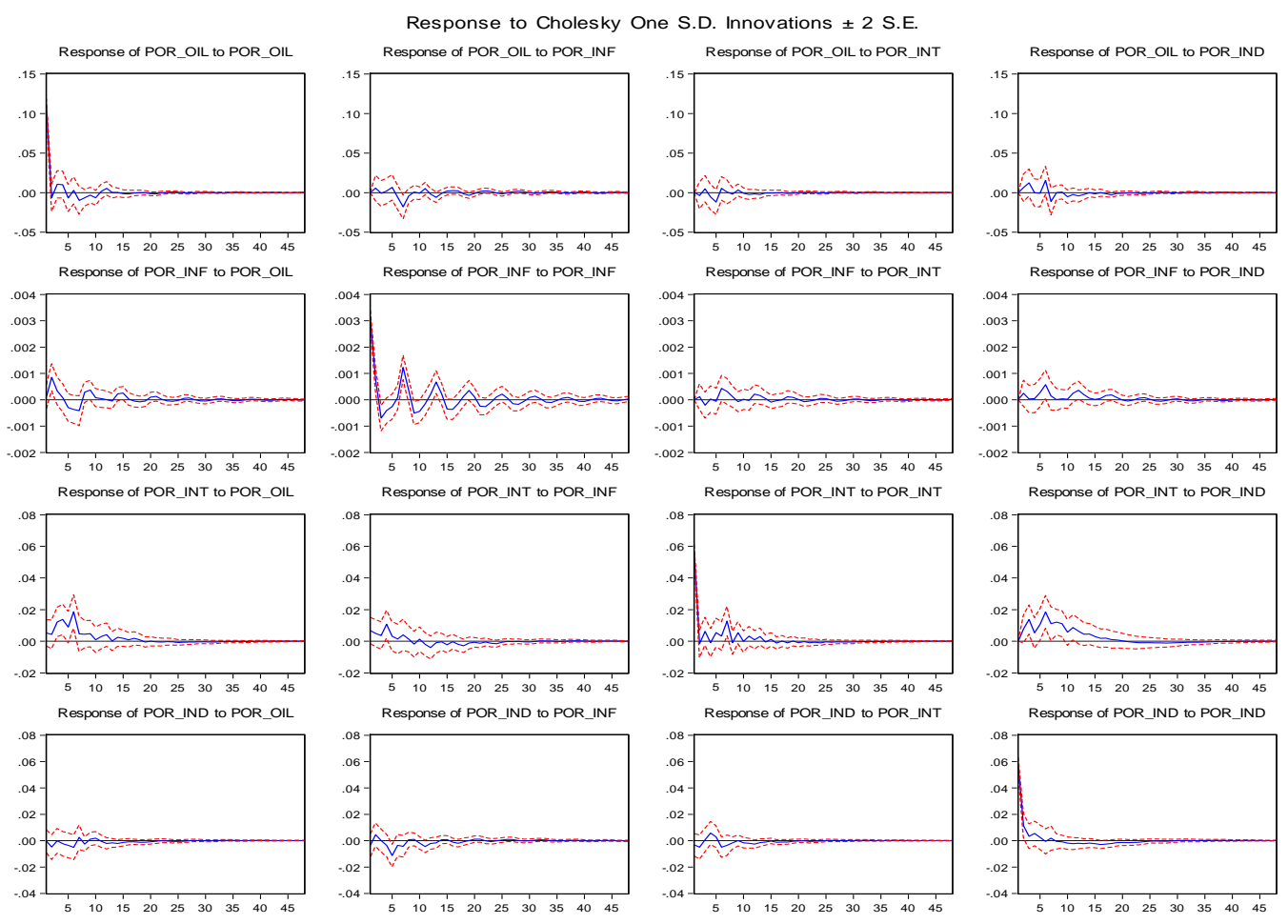

\section{Russia}
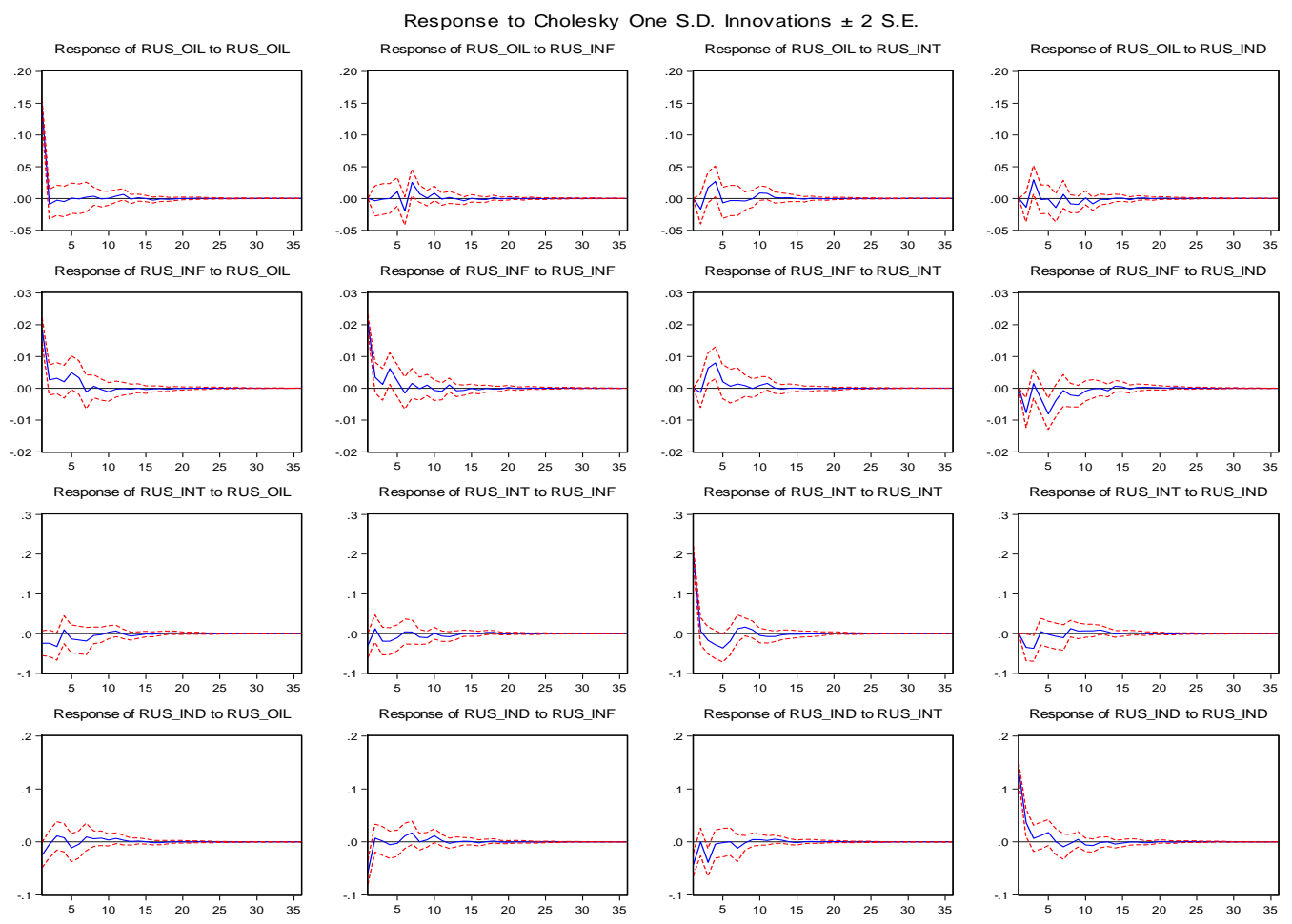